\title{
Small Intestine Cancer Pathologic TNM Finding v8
}

National Cancer Institute

\section{Source}

National Cancer Institute. Small Intestine Cancer Pathologic TNM Finding v8. NCI

Thesaurus. Code C133830.

A pathologic finding about one or more characteristics of small intestine cancer, following the rules of the TNM AJCC v8 classification system. 